\title{
Modern Ceramic Chafing Dishes in Northern Poland
}

\author{
Joanna Dąbal ${ }^{a}$
}

\begin{abstract}
Ceramic chafing dishes are very unique finds. Archaeological research in Poland, until now, has provided no information on these artefacts. In this paper, a selection of finds from Gdańsk and Słupsk are presented for the first time. The paper also includes some preliminary remarks about consumption patterns in modern Northern Poland.
\end{abstract}

KEY-WORDS: Chafing dishes, ceramic, Poland, Gdańsk, Słupsk, archaeology

\section{INTRODUCTION}

Chafing dishes are domestic utensils used for holding burning charcoal or other combustible materials, to cook food or to serve it hot at the table. The terms used for the dishes have similar origins in various European countries. In France, the most commonly used names are chauffe plat or réchaud de table. A similar term is used in English - "chafing dish". The Spanish names for these vessels are anafe or anafre. The Dutch name for these vessels is komfoor. Finally, German names used for both metal and ceramic vessels are Wärmeschale or Wärmpfanne. A suitable Polish name is podgrzewacz. All the terms used, establish the major use of these vessels, which is for warming dishes.

During the past few centuries, chafing dishes were made of clay or metal and have differed in shape. Two general forms are distinguishable, the first one is a perforated bowl- shaped form with a pedestal, and the second one, a vessel with a perforated pot or bowl shaped body with three pods. Usually, both metal and ceramic dishes have several knobs attached to the rims, and openwork or perforations in the upper part of the body. Further, some more elaborate forms are known, like for example those found in France and Germany (Ravoire 1991: 228; Niederfeilner 2004: 60-6I, I07; Bertrand and Robin 2019: fig. 13).

a Institute of Archaeology and Ethnology, University of Gdańsk, Bielańska Street 5, 80-85I Gdańsk; e-mail: joanna.dabal@ug.edu.pl; https://orcid.org/oooo-oooI-7325-2282 
8o $\mid$ Joanna Dąbal

The origins of these vessels have not been determined, although there are some suggestions in the literature. Carmen Bosch Ferro and Marina Chinchilla Gómez point to Mesopotamia and Southern Asia as origins of this form (1987: 492). This corresponds with more elaborate studies of chafing dishes found in South-East Europe at various archaeological sites within the Byzantine Empire area and its surroundings from the 7th to 12th centuries (Vroom 2008: 293-294; Vassiliou 2016: 252-253; Vakasira 2020). Then, early Spanish finds are dated from the IIth to I3th centuries (Bosh Ferro and Gómez 1987: 493). One I3th century ceramic example of a chafing dish was found in London, Britain (Pearce et al., 1985: 44, II4). There is not much information on other medieval finds, except for I5th century metal, and several ceramic objects, which are known to have come from the Netherlands and Britain (Lewis 1973: 6I-63; Bartels 1999: I23-I24; Gawronski ed. 2012: 167). Metal chafing dishes are generally dated in Britain from the i5th century (Lewis 1973: 6I-63). Early metal I6th century vessels are known to have come from Germany and France (Baumgärtel 1981; Soulat 2015).

Archaeological literature has paid very little attention to this assortment of vessels from the modern period. Limited data exists in archaeological reports, with ceramic chafing dishes usually being mentioned in between other vessels. Those artefacts dated from the I6th century to the I8th century are known from: Spain (Amores Carredano and Chisvert Jiménez 1993: 292); France (Labaune-Jean and Pouille 20I2: 3-5, 78-79, Bertrand and Robin 2019: 355); the Netherlands (Klijn 1995: 153-154, Bartels 1999: 123-I24, Gawronski 20I2: 198, 228, 238, 274, Meulen and Smeele 20I2: 72); Belgium (Herremans and De Clercq 2013: 93); Germany (Niederfeilner 2004: 6I); Ireland (McCutcheon and Meenan 20II: IO2, IO7) and Britain (Holling 1969: 28, Huggins 1969: 80-8I, Fanning et al., 1975: 109-III, Haslam 1975: 180, Coleman-Smith 2002: I48-I49). Recently published information about chafing dishes found in the Czechia, dating from the second half of the I6th century to the 17th century, attributed them to local Prague workshops (Blažková 2019: II6-II9). These finds, together with vessels from Gdańsk and Słupsk in Poland, extend the range of the dispersion of ceramic chafing dishes to Central Europe in the modern period.

The use of ceramic chafing dishes in the I9th and 2oth centuries is very infrequently reported. Most known are vessels from the Netherlands (Klijn 1995: 155-I63; Meulen and Smeele 2012: 206). We know much more about metal utensils from the second half of igth century, mainly from the American and British commercial markets (House Furnishing Review I894: 224). In this period, the markets were stimulated by advertisements (Fig. I), and in the second half of the century, cookbooks dedicated to chafing dishes appeared (Herrick 1895; Hill i899). In this period, a new fashion for "smart" metal equipment comitted to modern women or modern housewife has been designed (in many advertisements these vessels were depicted as offered as wedding gifts or as Christmas gifts, as well as being "suitable" to a modern house (House Furnishing Review I894: 224; I897: 49; I899: II, I4, 43; 1903: 177, 385; 1909: 7). 


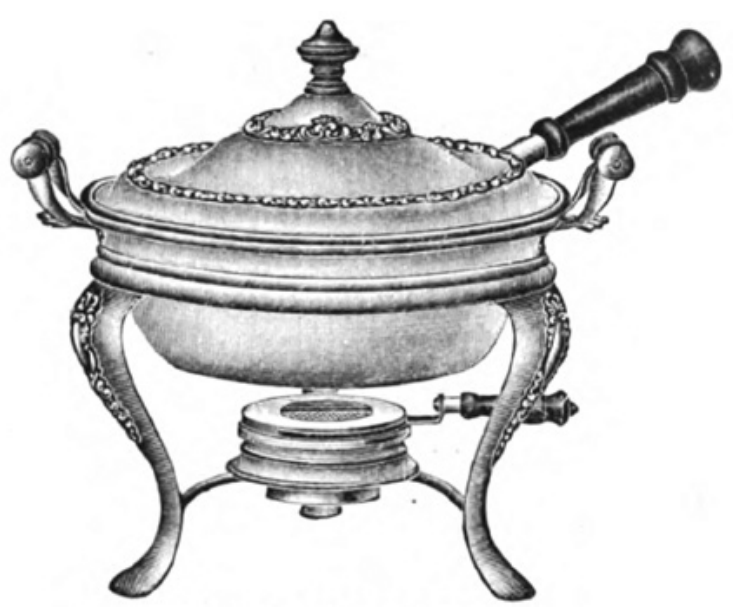

Fig. 1. Metal chafing dish, the early 20th century, The Manning, Bowman \& Company Advertisement (Meriden, Connecticut, USA; sources: House furnishing review 1903: 385).

\section{LOCATION OF SITES AND CONTEXT}

The six ceramic chafing dishes discussed in this paper were found in Słupsk and Gdańsk on the Polish north coast. For published ceramic assemblages from Northern Poland (Gdańsk Pomerania, West Pomerania) no analogous dishes were found. On present evidence, these recently discovered ceramic chafing dishes from these two locations seem to be the only known finds in these regions of northern Poland.

Słupsk is a small town located about $\mathrm{I} 6 \mathrm{~km}$ south of the Baltic shore. The history of the settlement dates back to the early medieval period. The growth and rising economic prosperity of the town lasted from the late medieval to early modern periods. The ceramic chafing dish was found during an excavation conducted in 2017 in the area of the old town square (Marczewski et al., 20I7; Fig. 2). During the excavation, the remains of the old Town Hall were discovered (Dąbal 2019: II9-I2I). The analyzed vessel was found within the medieval Town Hall walls in the demolition layer dated by the excavation team to the i7th century. The raw materials from this feature are mixed and contain artefacts dated from the late isth century to the second half of I7th century, with the majority of the finds dating to the 17 th century.

Five other ceramic chafing dishes were found in Gdańsk (Fig. 3). The city is located on the shore of the Baltic Sea at the mouth of the River Vistula. The urban complex was founded as an early medieval settlement and became a major South Baltic trade centre in the late medieval period with growing economy in modern times. Five 

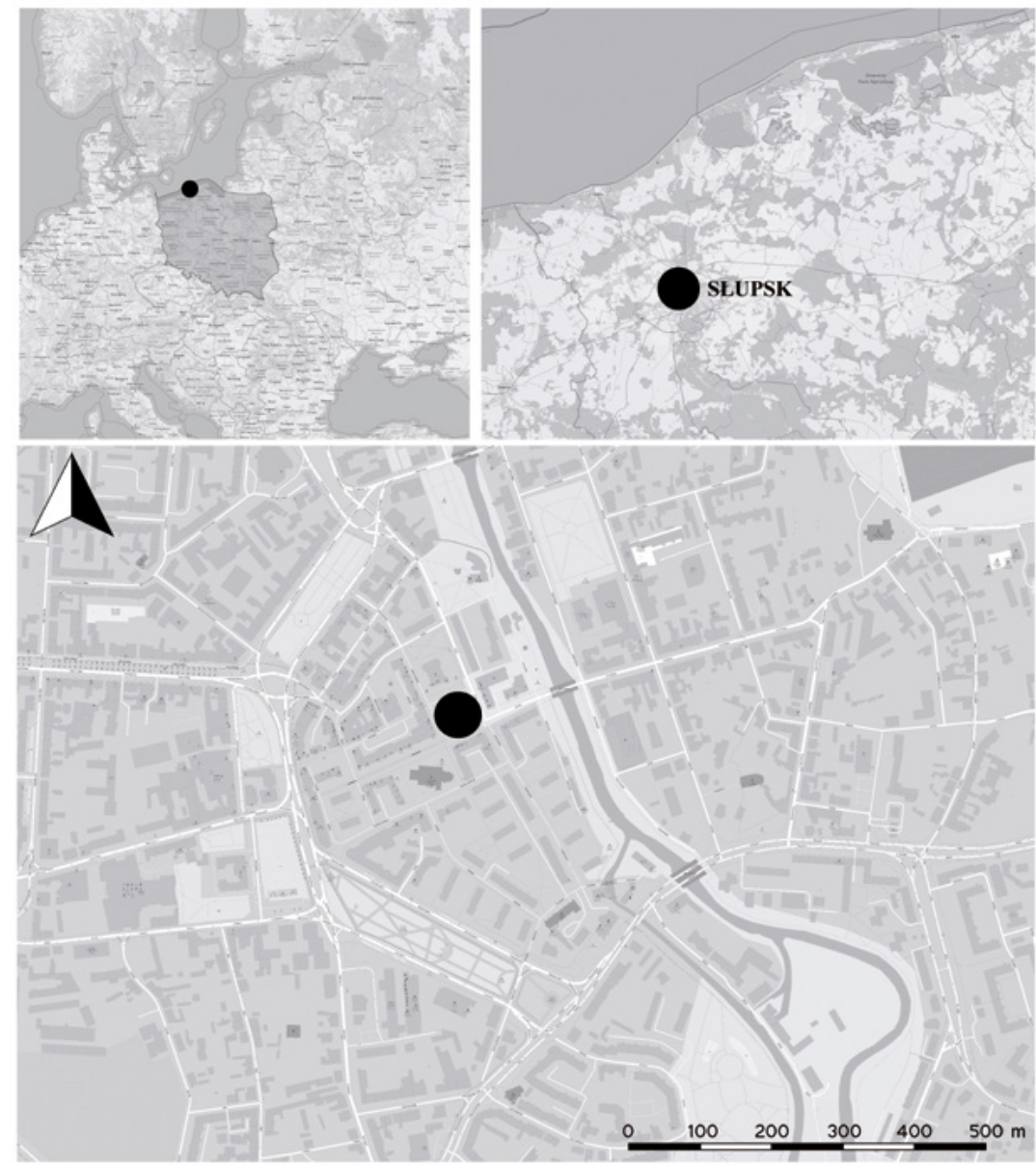

Fig. 2. Słupsk, Old Market Square, plot No. 706/13. Location of the archaeological site (AZP 9-29). Map background: OpenStreetMaps@

chafing dishes were discovered in the south-eastern outskirts of the I6th-17th century city, located then within the area of the fortifications. The artefacts were found in two archaeological sites located at 60 Łąkowa Street (Sadowa Apartments; 2019 excavation; Longa-Prager 2020) and 4-5 Reduta Wyskok Street (20I8 excavation; Kocińska 2020). Both localizations refering to the city sectors which were drainaged during the 17 th and early i8th centuries and gradually become housing quarters. One chafing dish from the 60 Eąkowa Street site was discovered in a levelling layer in the context of other finds dated from the 17 th to early I8th centuries. Four vessels from the $4-5$ Reduta Wyskok 


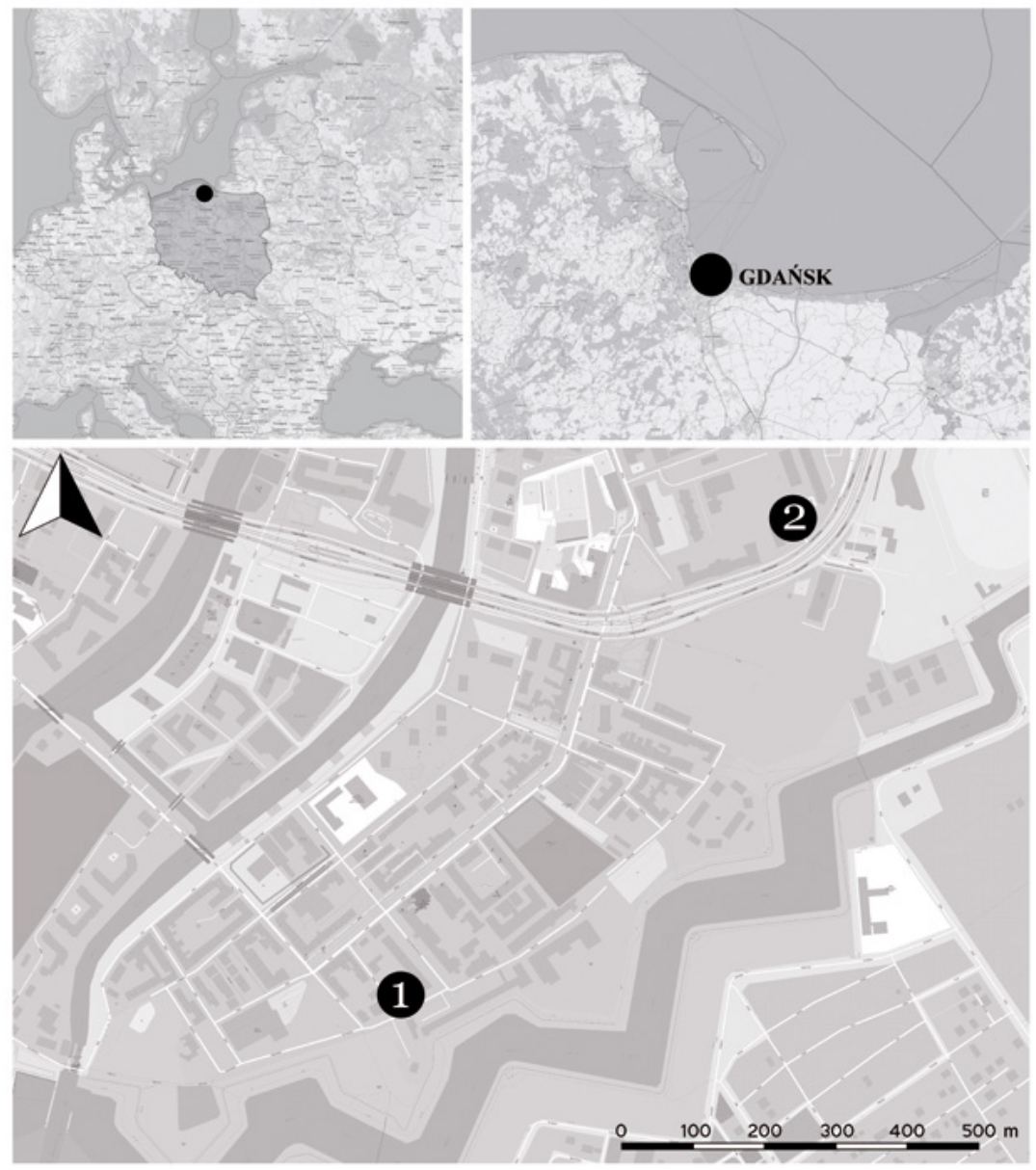

Fig. 3. Gdańsk, 4-5 Reduta Wyskok Street (1), 60 Łąkowa Street (2). Location of the archaeological sites (AZP 12-44/147; AZP 12-44/203). Map background: OpenStreetMaps@).

Street site were discovered in levelling layers dated to the I8th century. The artefacts were found in the context of materials dated from the early 17 th century to the 18 th century.

\section{CHAFING DISHES FROM SŁUPSK AND GDAŃSK}

The six wheel turned, redware chafing dishes were distinguished from the ceramic assemblages excavated from three archaeological sites located in Gdańsk and Słupsk. 
All utensils are partly preserved. Each of them is described with fabric information and metrical data.

The first chafing dish is preserved only as a pedestal and a fragment of a bowl. The body ware is made of fine clay matrix with a scatter of fine sand and fired buff-red. It has a lead glazed upper part (Fig 4). Some irregular splashes of iron wash (or a dusty splash of glaze) can be recognized on the lower part of the vessel's body. The bottom is about $9.7 \mathrm{~cm}$ in diameter. The conical pedestal is $3.3 \mathrm{~cm}$ high. A triangular opening was cut in the pedestal which has an additional small circular vent. Only a little part of the upper bowl is preserved. The connection between the pedestal and the bowl is vented with seven circular openings from $3.5 \mathrm{~mm}$ to $7.4 \mathrm{~mm}$ in diameter. No traces of use were noted on the surface and interior. This vessel was found in a context dated generally to the I7th century. Most of the ceramics in this assemblage (IOI7 fragments) were represented by lead glazed redware and some slipware. No faience sherds were noted. The general dating of the context referred to several later finds dated to the second half of the 17 th century. The material context indicates that the chronology of the vessel might be considered to be for the second half of the i6th century to the early i7th century.

The second chafing dish is preserved only as a part of the rim with one knob (Fig. 5). The ware is rough gritty fabric with quartz sand and fired dark red. The vessel is green glazed. The bowl rim is $24 \mathrm{~cm}$ in diameter and the knob placed on the rim is about $3 \mathrm{~cm}$ high. Under the rim, eight circular vents, each of about $4 \mathrm{~mm}$ in diameter are preserved. The utensil was discovered in Gdańsk during the excavation at Łąkowa Street. The context is dated to the early i8th century. The ceramic assemblage here is very small (II5 fragments), and 28 of them date back to the 17 th century.

A group of four chafing dishes was found in Gdańsk at 4-5 Reduta Wyskok Street. All of them differ in details regarding their shape and fabric.

Two in the assemblage were found in the same context (Fig. 6). The first chafing dish is preserved only as a part of the rim with one knob and a broken horizontal handle (Fig. 6:I). The vessel is rough and sandy fabric, buff-red fired and green glazed. The rim is $18 \mathrm{~cm}$ in diameter. The body seems to be a little $S$-shaped with a barely visible ledge placed at the height of the horizontal handle. The second is a chafing dish preserved only as a small part of the rim with a knob (Fig. 6:2). The body ware is made of gritty clay with large quartz sand fractions. The dish was fired dark red. The vessel is green glazed, but the outer glaze has been applied on a white slip. The rim is $17 \mathrm{~cm}$ in diameter. The body seems to be a little belly shaped. Five circular vents are preserved in the body. Both chafing dishes were found in the same context, dated to the I8th century, but most of the ceramic assemblage (4II fragments) dates back to the 17 th century. The general dating of these two vessels, referring to the context, is considered to be the i7th century.

The third chafing dish from this site is preserved only as a part of the rim (Fig. 7). The body ware is fine clay matrix with some medium sized quartz sand fractions and 

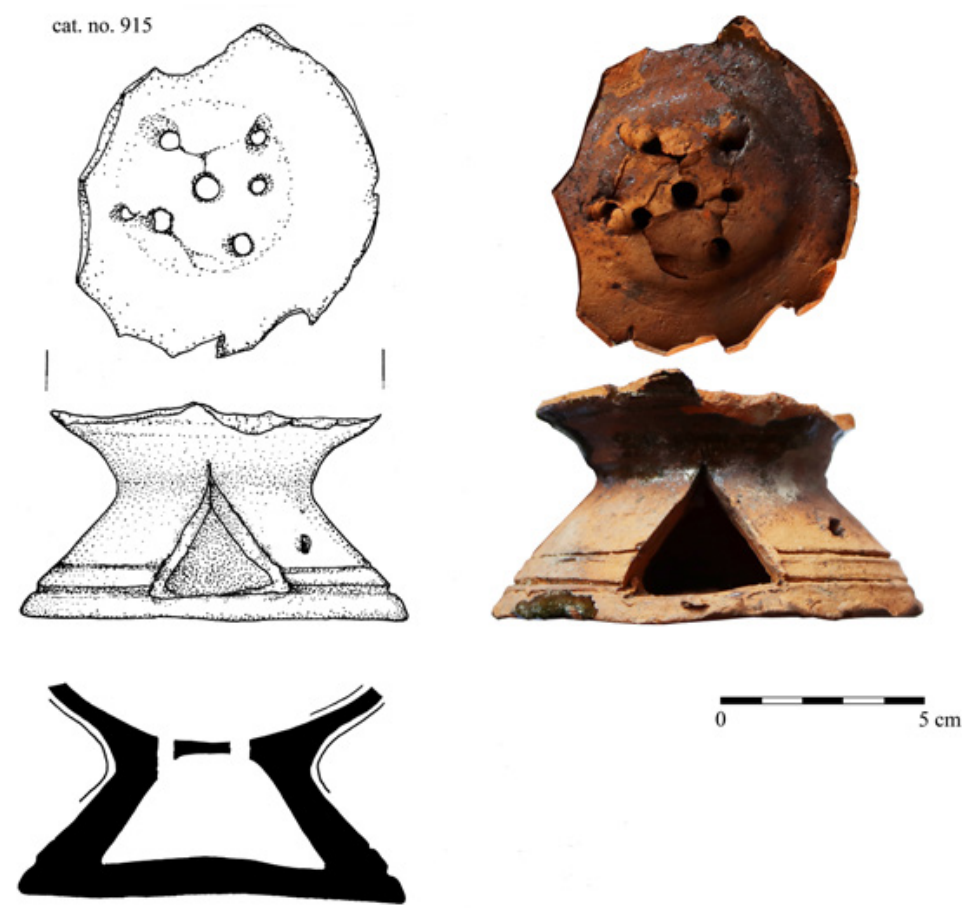

Fig. 4. Słupsk, Old Market Square, plot No. 706/13. Chafing dish. Drawn by A. Dmitruczuk. Photo by J. Dąbal.
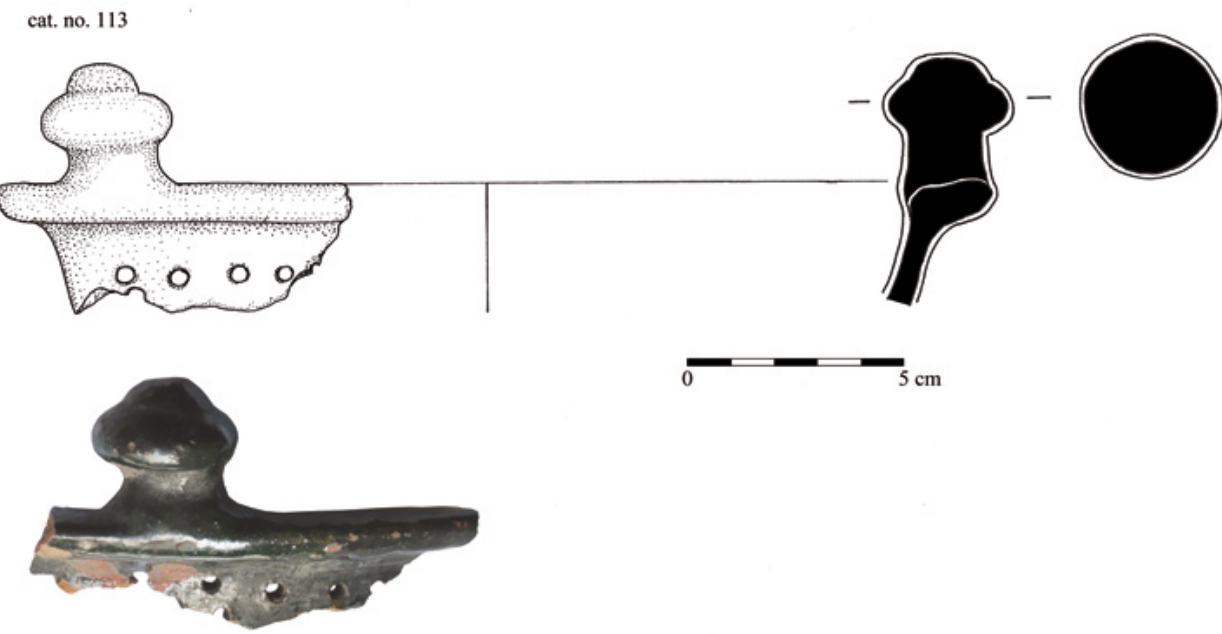

Fig. 5. Gdańsk, 60 Łąkowa Street. Chafing dish. Drawn by A. Dmitruczuk. Photo by J. Dąbal. 
$86 \mid$ Joanna Dąbal

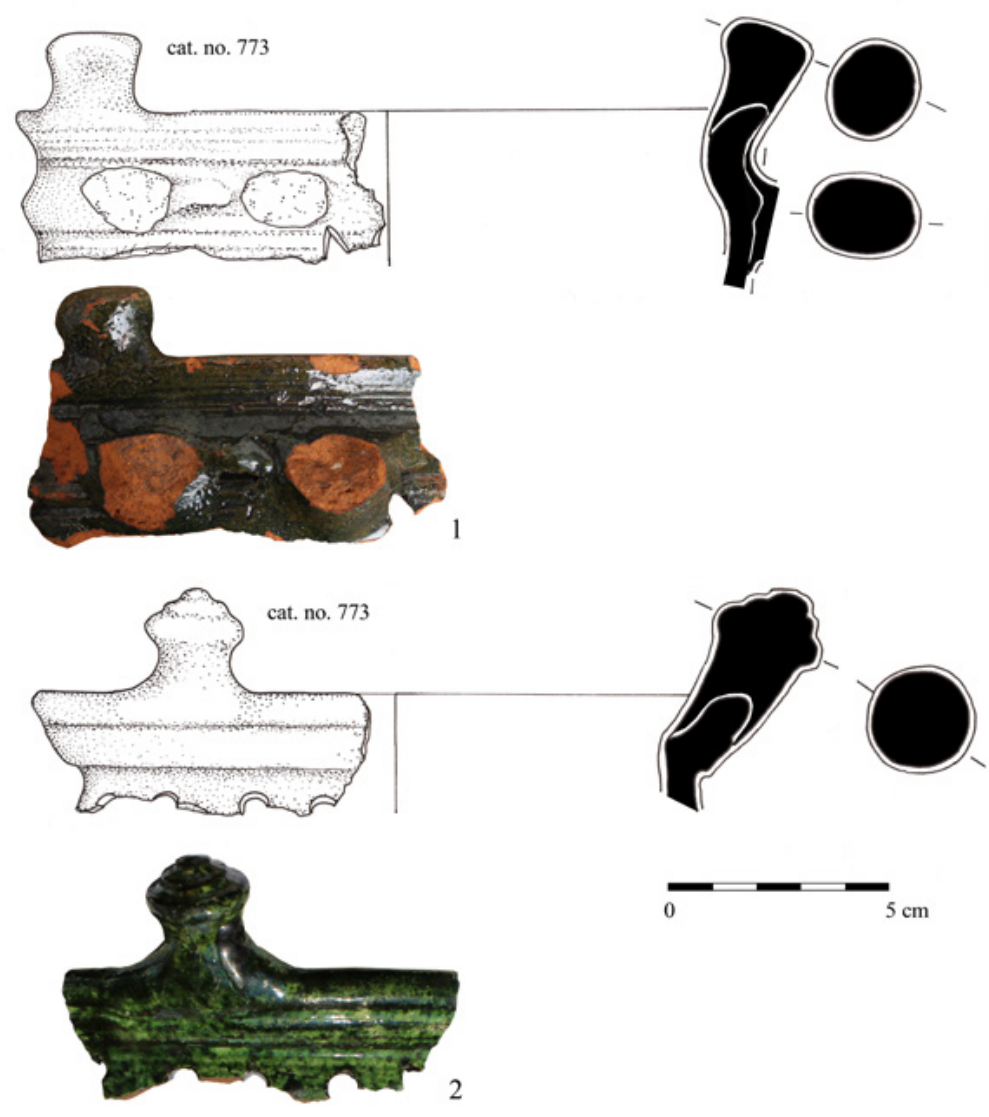

Fig. 6 . Gdańsk, 4-5 Reduta Wyskok Street. Chafing dishes. Drawn by A. Dmitruczuk. Photo by J. Dąbal.

fired pale dark red. The vessel is green glazed. Both surfaces are covered with glaze on white slip. The edge of the vessel is $15.5 \mathrm{~cm}$ in diameter with an additional double ledge applied around the rim. In the body of the partly preserved vessel, two triangular vents are noted. The context is dated by the excavation team to the I8th century, although most of the ceramic assemblage (I47 fragments) date back to the 17 th century.

The last chafing dish is preserved only as a part of the rim with one knob (Fig. 8). The body ware is rough and sandy fabric, buff-red fired. The light green glaze on the surfaces of the vessel has been applied on white slip. The vessel is in a very poor condition with a oxidized glaze. The body of the vessel was probably bowl shaped. The rim is $24 \mathrm{~cm}$ in diameter. Two partly preserved circular vents were noted in the body. The 
cat. no. 975

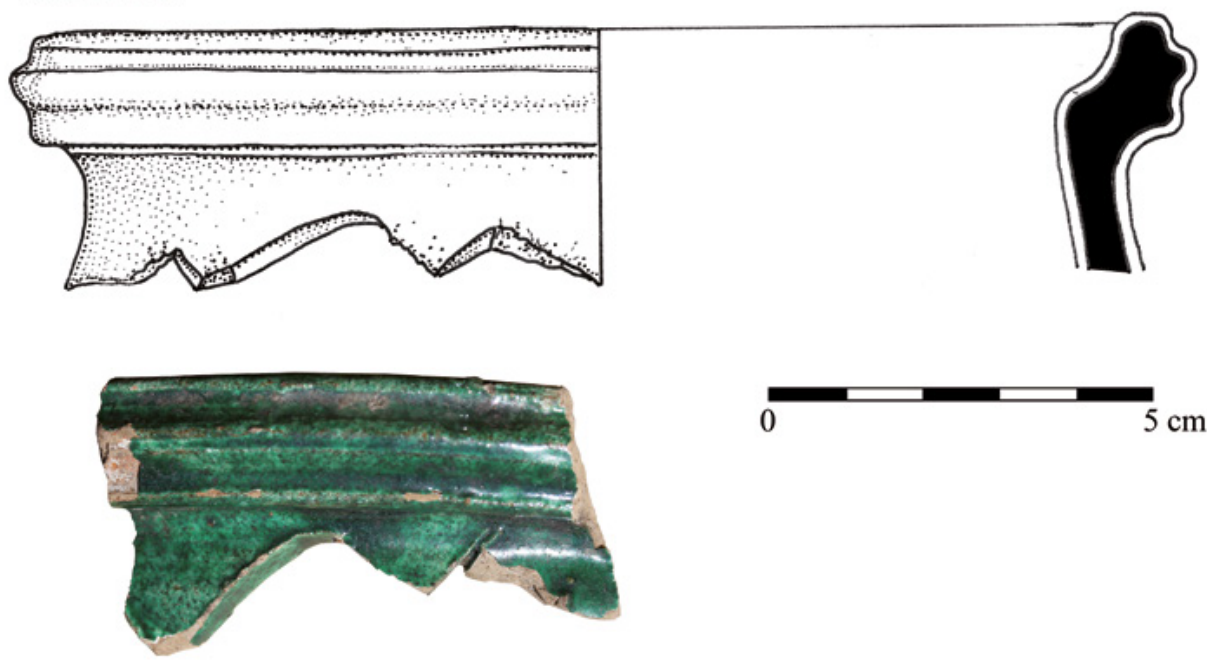

Fig. 7. Gdańsk, 4-5 Reduta Wyskok Street. Chafing dish. Drawn by A. Dmitruczuk. Photo by J. Dąbal.

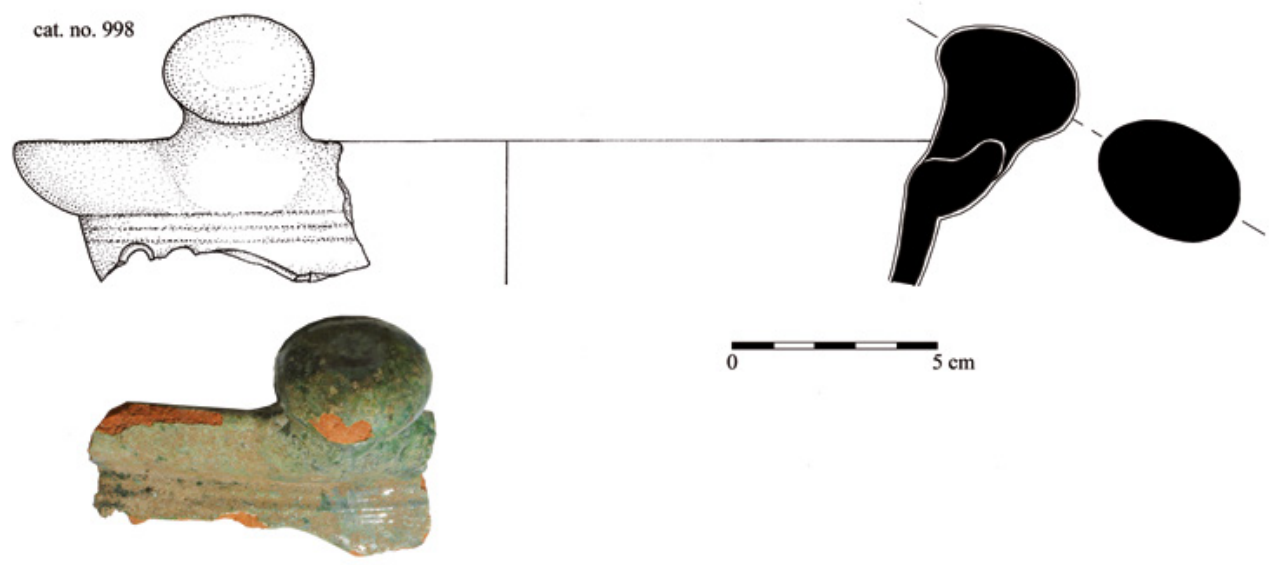

Fig. 8. Gdańsk, 4-5 Reduta Wyskok Street. Chafing dish. Drawn by A. Dmitruczuk. Photo by J. Dąbal. 
vessel was found within a small ceramic assemblage ( 8 fragments) from the context dated by the excavation team to the i8th century, although ceramics from that context are dated to the 17 th century. The vessel's chronology is considered to be the i7th century.

\section{DATING OF THE FINDS}

The archaeological contexts (levelling layers) of all the chafing dishes range between the I7th and I8th centuries, but the chronology of particular finds and assemblages dates back from the 15th to I8th centuries, with a predominance of 17th century materials. The final dating of vessels was set with reference to their fabric and rim shapes. General technological attributes for redwares, like iron splashes on the pedestal under light glazing (Fig. 4), green glazing (Fig. 5, 6:I) and green glazing applied on engobe (Fig. 6:2, 7-8), are indicators for dating them from the second half of the 16th century to the 17 th centuries. Because of the rarity of ceramic chafing dishes in archaeological assemblages that could be used as further reference, for comparing the shapes of ceramic bodies and rims, profiles of pots, tripods and bowls were used. The vessels with olive glazing and horizontal handles (Fig. 6:I) were formed in the 16th century manner. Similar rim shaping is displayed on chafing dishes from Dordrecht, the Netherlands dated from I550-I590 (Bartels 1999: 748). Late I6th century dating might also be considered for a bowl shaped, green glazed body of a chafing dish from Gdańsk (Fig. 5). Similar rims are recognized in chafing dishes found in Tiel dated from I540-1570 and a ceramic assemblage of bowls, tripods and chafing dishes found in Freiberg, Germany dated to the late I6th century and later (Bartels 1999: 748; Niederfeilner 2004: 60-6I, I07). Three other vessels, green glazed on engobe (Fig. 6:2; 7-8), were dated according to the shapes of the rims of ceramic assemblages from Lyon, France, Donyatt and Cove, Britain and Dordrecht and Nijmegen, the Netherlands (Haslam I975: 180, I82; Bartels 1999: 651, 723, 753; Coleman-Smith 2002: 133, I40, I48; Bertrand and Robin 20I9: 352, 355, 363). A similar chafing dish to the one from Słupsk, consisting of a preserved pedestal with a triangular vent (Fig. 4), were found in Dutch and British ceramic assemblages and dated from the late i6th century to the first quarter of the I7th century (Haslam 1975: 180, I82; Hurst et al., 1986: 80). These dating conclusions refer to the probable time of use of the vessels, although they were excavated from layers generally dated to the $\mathrm{I} 7 \mathrm{th}$ and $\mathrm{I} 8 \mathrm{th}$ centuries.

\section{DISCUSSION}

While dating chafing dishes found in Poland does not cause confusion and generally points from the late I6th century to the first half of the I 7 th century, their origins are 
very uncertain. All of analysed chafing dishes are not local products. At this stage of research, three destinations are considered as a preliminary place of the workshops. Most probable is their French (probably central France) or British origin (most probably the London basin); in one case, a Dutch origin may be concidered. The indicators for this preliminary conclusion are the fabrics and forms. Both French and British forms are most alike to those found in Gdańsk and Słupsk. These have a conical pedestal and round shaped knobs on the rim, which are found in France and Britain (Moorhouse 1970: 44, 46; Coleman-Smith 2002: 148-I49; Horry 2015: Fig. II5; Bertrand and Robin 2019: 363). In the case of the vessel preserved in the pedestal part, the most alike are French and British-type chafing dishes (Haslam 1975: 180, 182; Pryor and Blockley 1978: 69, 71, Fig. 17; Pearce et al., 1985: 4-5). Most doubts about the origin of chafing dishes are concerned with the vessels preserved in part of the rim with a horizontal handle (Fig. 6:I), or a rim with a triangular vent (Fig. 7). The exact analogous chafing dishes have not been found. Redware vessels of that period with horizontal handles are very common in the Netherlands, some analogical types of knobs (Fig. 6:I) were also recognized among Dutch examples, although no comparisons with fabrics have yet been identified (Klijn 1995: 153-I54). More data and further comparative studies on chafing dishes are necessary for final conclusions on their origins. At this stage of research, confirmed cases of locally-produced chafing dishes come from France, Britain, the Netherlands and recently from the Czechia (Mayes 1968: 73-74; Crossley 1972: 65; Haslam 1975: 180, I82; Coleman-Smith 2002: I48-I49; Meulen and Smeele 2012: 72, 206; Horry 2015: Fig. II5; Blažková 2019: II6-II9).

\section{CONSUMPTION PATTERNS}

The group of ceramic chafing dishes discussed here is generally dated from the late I6th century to the i7th century. Although the range of archaeological and historical data is wide (Kizik 2000; 200I; 2020; Barylewska-Szymańska 20I5), for this period we know very little about consumption patterns in Gdańsk and Słupsk. Chafing dishes are rare finds in Germany, the Czechia and in Poland and are mainly related to city spaces. These types of vessels are better known from France, Britain and the Netherlands. Although some locally produced forms were discovered, between the I6th and 17 th centuries these are still rare finds, even in the mentioned areas. Referring to the macro context of the finds from Gdańsk and Słupsk presented here, the chafing dishes were more probably used for warming up dishes or finishing dishes by the table, while using them as small portable kitchens (as suggested in the literature) is less probable. In Gdańsk and Słupsk, the manner of consumption with the use of chafing dishes at the table might have been influenced by Dutch or British inhabitants and merchants of the Pomerania Region. In the Netherlands, the chafing dishes 
9o $\mid$ Joanna Dąbal

were, for example, used to serve meat that was initially fried in the kitchen and then the cooking was finished at the table. The preparation of dishes in this way was called "between two dishes" (tusschen twee scotelen). The other example cited in the literature is the use of these vessels to warm up and finish fish or eggs (Jong-Lambregts 2004: 42-43).

The alternative purpose of these vessels might have been to hold burning charcoal or other combustible materials during the fiestas used for lighting tobacco pipes. Preliminary research by André Leclaire was directed to the analysis of historical paintings (2009). Although I7th century Dutch pictured examples, referred to by the author, are tripods without vents or knobs (Leclaire 2009: 189-196).

Analyzing the very scant images of ceramic chafing dishes in paintings, some preliminary remarks can be made about the context of the vessels. A well-known painting with a chafing dish was painted by Diego Vélazques in about the year 1618. In "An Old Woman Frying Eggs" we can see a wealthy young boy whose dish is being warmed by an older lady. The second example is the work of Pieter Cleasz, "Still life", from the year I627 (Fig. 9). From the arrangement of details, like silver plates and glass vessels, we can conclude that the setting is from a wealthy, or at least, urban background. Compared to I8th century paintings like "Bulle de savon", attributed to Étienne Aubry (Horry 20I5: fig. 272) and "Les Apprêts d'un déjeuner",

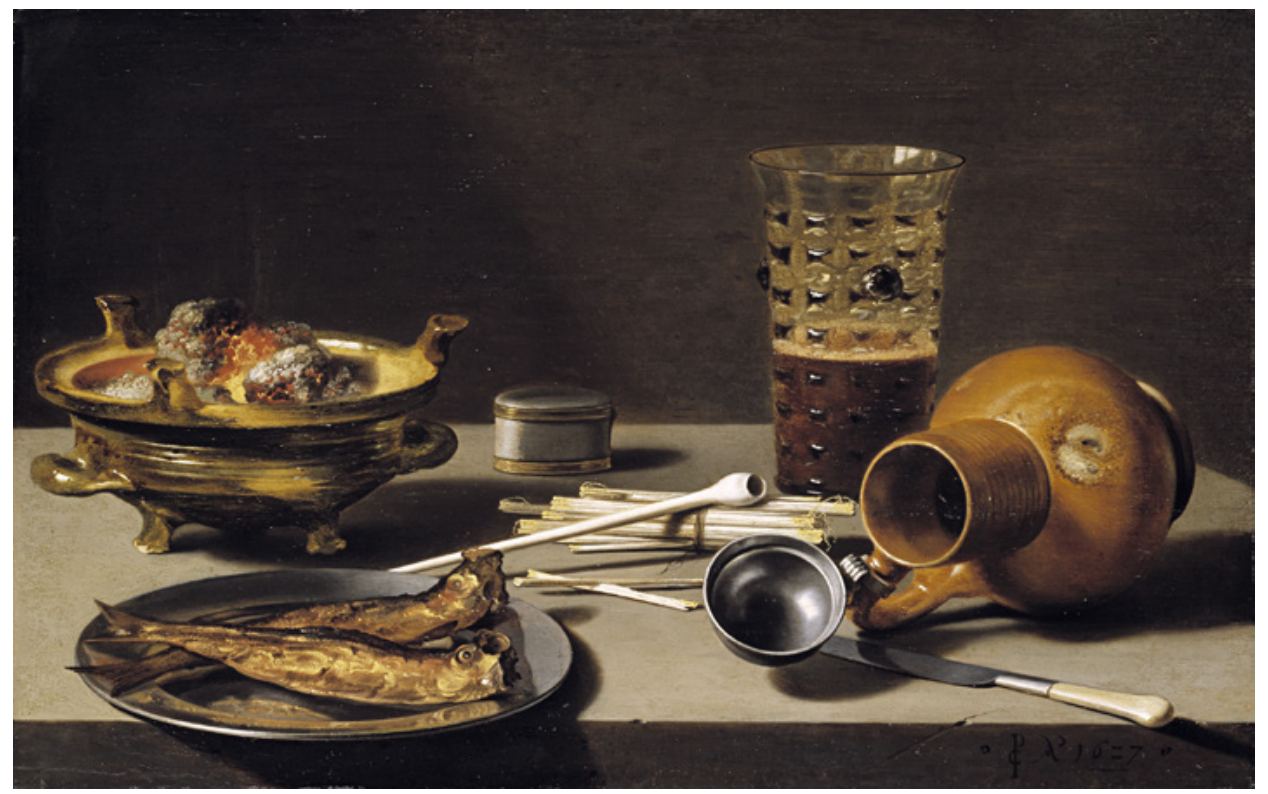

Fig. 9. Pieter Cleasz, "Still life", from the year 1627 (licenced by Timken Museum of Art). 
painted by Bernard Lépicié, it might be seen that the context of the background for chafing dishes has changed. Both paintings present less than wealthy interiors with chafing dishes used for preparing meals on the table. These examples might be considered as initial arguments for a further wider study of the value of ceramic chafing dishes.

Based on the archaeological contexts of the 16th-17th century ceramic chafing dishes, which are limited to wealthy places (meaning a generally higher status of the inhabitants) and the wider market of accessible products, we can distinguish several types of areas where we may expect to find them in excavations, they occur in ceramic assemblages from palaces, centres of international trade, and administrative districts of cities. This background indicates that ceramic chafing dishes of that period, used during table fiestas, were markers of wealth and/or urban life. Furthermore that concerns the habits of long lasting fiestas or "ceremonial" meals.

\section{CONCLUSIONS}

Ceramic chafing dishes are very uncommon finds. Archaeological research in Poland has, until now, provided no information on these artefacts. Furthermore no synthetic studies have been undertaken in a broader European context. The context of the use of chafing dishes, derived from archaeological data and initially considered with iconographical evidence, indicates the necessity for further research in the future. However, the presence of these rare imported ceramic vessels in Gdańsk and Słupsk is evidence for the range of dispersion of this type of finds in Central Europe. The origin of the chafing dishes found in Poland is uncertain, although some preliminary remarks on French, British and Dutch references were taken. Their dating generally points from the late i6th century to the first half of the I7th century and having regard to the very limited data base of these ceramics, those from Gdańsk and Słupsk are currently the "oldest" known examples from the region. These Polish examples are definitely later than those of other north European countries, especially the Netherlands and Britain (Lewis 1973: 6I-63; Bartels 1999: 123-I24; Gawronski 20I2: I67). Dating ceramic chafing dishes and the identification of their workshops would be crucial for developing researches on consuming patterns in northern and central Europe. The rarity of ceramic chafing dishes might be interpreted that they were 'precious' (but not necessarily in the meaning of being expensive). It can therefore be concluded that the presence of these finds indicates interpretation of their use in towns amongst their wealthier inhabitants or their use in the international context as part of the urban "way of life". 
$92 \mid$ Joanna Dąbal

\section{REFERENCES}

Amores Carredano, F. and Chisvert Jiménez, N. 1993. Tipología de la cerámica bajomedieval y moderna sevillana (s. XV-XVIII). SPAL: Revista de prehistoria y arqueología de la Universidad de Sevilla 2: 269-325.

Bartels, M. 1999. Steden in scherven. Vondsten uit beerputten in Deventer, Dordrecht, Nijmegen en Tiel (I250-I900). Zwolle, Amersfoort.

Barylewska-Szymańska, E. 20I5. Od piwnic po strych. Wnętrza domów gdańskich drugiej potowy XVIII wieku. Warszawa-Gdańsk, Res Gedanenses Studia i Materiały Muzeum Historycznego Miasta Gdańska 7.

Baumgärtel, O. 198I. Das “messen pfendlein auf den Tish”. Nürnberger Speisenwärmer aus Messing der Renaissance u. des Barock. Kunst u. Antiquitäten 6: 44-54.

Bertrand, É. and Robin, L. 2019. La table verte: la vaisselle d'un dépotoir de la fin de la Renaissance à Lyon (place Abbé Larue, se arr.). Revue archéologique de l'Est 67: 35I-370.

Blažková, G. 20I9. Painted Pottery in Bohemia. Slipware of the I6th and the 17th Centuries. In G. Blažková and K. Matějková (eds), Europa Postmediaevalis 2018. Post-medieval pottery between (its) borders, II5-I27. Gloucester.

Bosh Ferro, C. and Chinchilla Gómez, M. 1987. Formas cerámicas auxiliares: anafes, arcaduces y otras. Arqueología Medieval española: II congreso 2: 49I-500.

Coleman-Smith, R. 2002. Excavations in the Donyatt potteries: site I3. Post-Medieval Archaeology 36(I): II8-I72.

Crossley, D. 1972. A Sixteenth-Century Wealden Blast Furnace: A Report on Excavations at Panningridge, Sussex, 1964-1970. Post-Medieval Archaeology 6(I): 42-68.

Dąbal, J. 20I9. Hiszpańskie naczynia na oliwę z badań archeologicznych w Słupsku. Gdańskie Studia Archeologiczne 7: I19-129.

Fanning, T., Hurst, J. and Lewis, J. 1975. A Mid Seventeenth-Century Pottery Group and Other Objects from Ballyhack Castle, Co. Wexford. Proceedings of the Royal Irish Academy. Section C: Archaeology, Celtic Studies, History, Linguistics, Literature 75: 103-II8.

Gawronski, J. (ed.). 20I2. Amsterdam Ceramics: A City's History and an Archaeological Ceramics Catalogue II75-20II. Amsterdam.

Haslam, J. 1975. The Excavation of a I7th-century Pottery Site at Cove, E. Hampshire. Post-Medieval Archaeology 9(I): I64-187.

Herremans, D. and De Clercq, W. 2013. The current state of post-medieval archaeology in Flanders. Post-Medieval Archaeology 47(I): 83-105.

Herrick, Ch. T. 1895. The Chafing-Dish Supper. New York.

Hill, J. M. I899. Salads, Sandwiches and Chafing-dish Dainties. With Thirty-two Illustrations of Original Dishes. Boston.

Holling, F. W. 1969. Seventeenth-century Pottery from Ash, Surrey. Post-Medieval Archaeology 3(I): 18-30.

Horry, A. 20I5. Poteries du quotidien en Rhône-Alpes, XVIe, XVIIe, XVIIIe sičcles: un panorama des techniques, des formes et des décors. Lyon.

House furnishing review. I894. House furnishing review 4 (January-June): 224.

House furnishing review. 1897. House furnishing review 9 (January-June): 49.

House furnishing review. 1899. House furnishing review I5 (January-June): II, I4, 43.

House furnishing review. 1903. House furnishing review 23 (January-June): 385. 
House furnishing review. 1909. House furnishing review 3I (July-December): 7.

Huggins, P. J. 1969. Excavations at Sewardstone Street, Waltham Abbey, Essex, 1966. Post-Medieval Archaeology 3(I): 47-99.

Hurst, J. G., Neal, D. S. and van Beuningen, H. J. E. 1986. Pottery produced and traded in north-west Europe 1350-1650. Rotterdam Papers VI. Rotterdam.

de Jong-Lambregts, N. 2004. Koken, bakken, braden en eten met aardewerk. Over de toepassing van gebruiksaardewerk uit archeologische context. In J.van Campen, K. Duysters, N. Fraenkel-Schoorl, S. Ostkamp and Ch. Smits (eds), De verborgen stad. Archeologisch onderzoek naar 750 jaar wonen in Alkmaar, 30-47. Amsterdam.

Kizik, E. 2000. Inwentarz pośmiertny kramarza gdańskiego, mennonity Hendrika van Dührena z I694 roku. Alamanach Historyczny 2: 185-208.

Kizik, E. 200I. Wesela, kilka chrztów i pogrzebów. Gdańsk.

Kizik, E. 2020. Gdańskie testamenty reciproce i praktyka tworzenia inwentarzy mienia w XVII-XVIII w. Kwartalnik Historii Kultury Materialnej 68(2): 205-222.

Klijn, E. M. Ch. F. 1995. Lead-glazed earthenware in the Netherlands. Arnhem.

Kocińska, K. 2020. Opracowanie wyników badań archeologicznych przy ul. Reduta Wyskok 4-sw Gdańsku, gm. Miasto Gdanisk, woj. pomorskie. Stanowisko 24, AZP I2-44/I47. Typescript in the Archives of the Pomorski Wojewódzki Konserwator Zabytków Wojewódzki Urząd Ochrony Zabytków in Gdańsk.

Labaune-Jean, F. and Pouille, D. 20I2. Répertoire des céramiques de Rennes aux XVe et XVIe siècles, à partir des découvertes du site hospitalier de la place Sainte-Anne (Ille-et-Vilaine, Bretagne). Revue archéologique de l'Ouest 29: 259-286.

Leclaire, A. 2009. A la Découverte des Couvets en Céramique. Journal of the academie internationale de la pipe 2: 189-193.

Lewis, J. 1973. Some Types of Metal Chafing-Dish. The Antiquaries Journal 53(I): 59-70.

Longa-Prager, A. 2020. Opracowanie wyników badań archeologicznych przy ulicy Sadowej $35 w$ Gdańsku. Stanowisko $\mathrm{nr} 86$ (AZP I2-44/203). Typescript in the Archives of the Pomorski Wojewódzki Konserwator Zabytków Wojewódzki Urząd Ochrony Zabytków in Gdańsk.

Marczewski, M., Naleźny, A. and Zielenkiewicz, A. 2017. Sprawozdanie z archeologicznych badań wykopaliskowych Starego Rynku w Stupsku, dz. nr 706/I3, AZP 9-29. Słupsk. Typescript in the Archives of the Wojewódzki Urząd Ochrony Zabytków Delegatura in Słupsk.

Mayes, P. 1968. A 17th-Century Kiln Site at Potterspury, Northamptonshire. Post-Medieval Archaeology 2(I): $55-82$.

McCutcheon, C. and Meenan, R. 20II. Pots on the hearth: domestic pottery in historic Ireland. Proceedings of the Royal Irish Academy: Archaeology, Culture, History, Literature. Special Issue: Domestic life in Ireland IIIC: 9I-II3.

Meulen van der, A. and Smeele, P. 20I2. De pottenbakkers van Gouda 1570-1940. En hun betekenis voor de geschiedenis van de Nederlandse keramiek. Leiden.

Moorhouse, S. 1970. Finds from Basing House, Hampshire (c. 1540-1645): Part One. Post-Medieval Archaeology 4(I): 3I-9I.

Niederfeilner, A. 2004. Vom Dorf zur Metropole des Erzgebirges: die Stadtkerngrabung "Theaterquartier" in Freiberg, Sachsen. Bamberg.

Pryor, S. and Blockley, K. 1978. A I7th-century Kiln Site at Woolwich. Post-Medieval Archaeology I2(I): 30-85. 
$94 \mid$ Joanna Dąbal

Pearce, J. E., Vince, A. G. and Jenner, M. A. 1985. A dated type-series London medieval pottery, part 2, London-type ware. Special paper $n^{\circ} 6$. London.

Ravoire, F. 199i. Un ensemble céramique du XVIe siècle: la fosse Li des thermes de Cluny à Paris. Archéologie médiévale 21: 209-270.

Soulat, J. 20I5. Les réchauds en alliage cuivreux dits « chafing dish » des XVIe-XVIIIe siècles en contexte archéologique: typologie, fonction et diffusion. Instrumentum 4I: 4O-44.

Vakasira, G. 2020. Experimental Study of Byzantine Chafing Dishes. EXARC Journal 2020(I): I-I5.

Vassiliou, A. 2016. Middle Byzantine Chafing Dishes from Argolis. Deltion of the Christian Archaeological Society. Series 4(37): 25I-276.

Vroom, J. 2008. Dishing up history: early medieval ceramic finds from the Triconch Palace in Butrint. Mélanges del'École française de Rome. Moyen-Age I20(2): 29I-305. 